\title{
REASONS THAT MADE AGED PEOPLE SEEK CARE AT A BASI C HEALTH UNIT
}

\author{
Mary Rosane Quirino Polli Rosa ${ }^{1}$ \\ Zuleica Maria Patrício ${ }^{2}$ \\ Maria Regina Silvério ${ }^{3}$ \\ Davi Rumel ${ }^{4}$
}

Rosa MRQP, Patrício ZM, Silvério MR, Rumel D. Reasons that made aged people seek care at a basic health unit. Rev Latino-am Enfermagem 2009 setembro-outubro; 17(5):670-6.

This quantitative study aimed to get to know the reasons that made aged people seek care at a basic health care outpatient clinic in the State of Santa Catarina, Brazil. The data was collected in the patient files of 401 aged people attended by the health team. Initial reading of these records evidenced 4634 reasons that, after qualitative analysis, were grouped under complaints and requests for attention. In a second analysis, these data were classified as $\mathrm{R}$ and $\mathrm{Z}$, according to ICD-10. The R category - complaints expressed by signs and symptoms- equals $64 \%$ of the reasons, with "pain" as the most common one. The other reasons, $36 \%$, corresponded to the $Z$ category, called requests for attention, represented by medicine prescription requests and attendance for health control. The study evidenced the complexity of this population's health care demands in the study region, showing the need for that service to develop specific and interdisciplinary care.

DESCRIPTORS: health of the elderly; public health; health promotion; international classification of diseases

\section{MOTI VOS QUE LLEVARON A LOS ANCI ANOS A BUSCAR ATENCI ÓN EN UNA UNI DAD BÁSI CA DE SALUD}

Estudio de abordaje cuantitativo, cuyo objetivo fue conocer los motivos que llevaron a los ancianos a buscar atención en un ambulatorio del servicio básico de salud de Santa Catarina. Los datos fueron recolectados de las fichas de 401 ancianos atendidos por el equipo de salud. La lectura inicial de los registros evidenció 4.634 motivos que, después de un análisis cualitativo, fueron agrupados en quejas y solicitud de atención. Esos datos, en un segundo análisis, recibieron clasificación de $\mathrm{R}$ y Z, según la CID-10. La categoría R -- quejas expresadas por señales y síntomas - sumó $64 \%$ de los motivos, siendo el "dolor" el más evidenciado. Los demás motivos, 36\%, correspondieron a la categoría Z, denominada solicitud de atención, representada por pedidos de medicamentos y atenciones para control de la salud. El estudio evidenció la complejidad de la demanda de la atención de la salud de esa población en la región investigada, mostrando la necesidad de que este servicio desarrolle una atención específica y de carácter interdisciplinar.

DESCRIPTORES: salud del anciano; salud pública; promoción de la salud; clasificación internacional de enfermedades

\section{MOTI VOS QUE LEVARAM I DOSOS A BUSCAR ATENÇÃO EM UMA UNI DADE BÁSI CA DE SAÚDE}

Estudo de abordagem quantitativa, cujo objetivo foi conhecer os motivos que levaram idosos a buscar atenção em um ambulatório de serviço básico de saúde de Santa Catarina. Os dados foram coletados em prontuários de 401 idosos atendidos pela equipe de saúde. A leitura inicial dos registros evidenciou 4634 motivos que, após análise qualitativa, foram agrupados em queixas e solicitação de atenção. Esses dados, em segunda análise, receberam classificação de R e Z, segundo a CID-10. A categoria R - queixas expressas por sinais e sintomas - somou 64\% dos motivos, sendo a "dor" o mais evidenciado. Os demais motivos, $36 \%$, corresponderam à categoria $Z$, denominada solicitação de atenção, representada por pedidos de receita de medicamentos e atendimentos para controle de saúde. O estudo evidenciou a complexidade da demanda de atenção à saúde dessa população na região pesquisada, mostrando a necessidade de aquele serviço desenvolver atenção específica e de caráter interdisciplinar.

DESCRITORES: saúde do idoso; saúde pública; promoção da saúde; classificação internacional de doenças

Universidade do Sul de Santa Catarina, Brazil: ${ }^{1}$ RN, M.Sc. in Public Health, Full Professor, e-mail: mary.polli@unisul.br; ${ }^{2}$ RN, Ph.D. in Nursing Philosophy, Ful Professor, e-mail: zucamp@hotmail.com; ${ }^{3}$ M.Sc. in Education, Faculty, e-mail: maria.silvério@unisul.br; ${ }^{4}$ Physician, Ph.D. in Epidemiology, Full Professor, email: davi.rumel@gmail.com. 


\section{NTRODUCTION}

Estimates appoint that the proportion of elderly in Brazil will increase from 7.3\% (11 million) in 1991 to about 15\% (32 million) in 2025, which is the current proportion of elderly in most European countries, where this transition was slower and has not been equated yet ${ }^{(1-2)}$.

In less than 40 years, the scenario has changed from the mortality characteristic of a young population to a picture of complex and burdensome diseases typical of third age, characterized by chronic and multiple diseases that take years, demanding constant care, continuous medication and periodical tests. The number of elderly grew from 3 million to 17 million in 2006 - a $600 \%$ increase in less than fifty years ${ }^{(3)}$.

In Brazil, the main causes of mortality in this age range are diseases of the circulatory system, that is, cerebrovascular causes. Reality in Santa Catarina does not differ from other regions in the Federation, as the largest part of deaths is due to strokes ${ }^{(4)}$.

From a Collective Health perspective, aging is a challenge of the contemporary world. In countries considered developed, the main causes of population aging are the socioeconomic changes society has experienced in the past century and which, however, only produced significant modifications in their demographic variables at the turn of the twentieth century $^{(3)}$.

Demographic growth in Brazil and the current epidemiological profile, with high levels of chronic and degenerative conditions, create concerns with the elderly population. This reality requires that society see the aging of its population as an individual and collective responsibility in the public sphere ${ }^{(5)}$. In this respect, the importance of the National Elderly Health Policy is highlighted, which aims to promote healthy aging, functional capacity maintenance and improvement, disease prevention and health recovery, so as to guarantee that elderly people can continue living in their environment and exercise their functions in society with independence and quality ${ }^{(6)}$.

These aspects pose important challenges to the health system, creating the need to set up an agenda for health policies that can respond to the different epidemiological transitions through actions aimed at early disease detection and health promotion $^{(7)}$.
Based on this logic, the health promotion paradigm is considered an important strategy to face with the health-disease problems in society. Health promotion actions put forward the exercise of citizenship with a view to individual and collective attitudes that can improve the population's living conditions and, consequently, health.

In this context, the Family Health Program (FHP), which the Brazilian Ministry of Health created in 1994, is a privileged space to put promotion in practice, as it aims to revert the current - more disease-centered - care model to one of comprehensive health care. This proposal is a determinant reference framework for the elderly population, as it allows the health team to get closer to the context of people's lives.

The community's participatory action, continuous training of the professionals involved in the program with a view to improving quality of life and health and promoting healthy aging appear as positive points for this approximation to actually take place.

The physiological and psychosocial changes that occur in this age range and their repercussions for the elderly's quality of life and health, in addition to the expectation of health promotion and the systemic view of the human being, make care delivery to this population more complex.

It has been observed that the growth in the number of elderly people increases the demand this population poses to health services, as this group presents a large quantity of chronic and disabling diseases when compared with other age groups ${ }^{(8)}$.

As this is an emerging situation in the basic care context, however, the care they receive lacks specific and systematic care actions directed at their needs. It can also be identified that, even when the elderly are inserted in prevention actions, the care is merely disease-focused. This situation derives from different aspects. These include the team's lack of systematic knowledge on elderly people's health conditions, the elderly's subjective aspects and team training for interdisciplinary care, directed at health promotion, in view of the complexity of the specific situations this population presents.

As the above factors are described in the guidelines of the National Elderly Health Policy, these should simply be complied with, including: promoting active and healthy aging; providing 
comprehensive elderly health care; stimulating participation and strengthening social control; offering training and permanent education to health professionals working in the Unique Health System (SUS) in the field of elderly health; disseminating information of the National Elderly Health Policy to SUS health professionals, managers and users and supporting the development of studies and research ${ }^{(6)}$.

The lack of more people and less diseasefocused care has been identified in basic health care services, including the place of study, during teaching, community service and research activities. As it is a teaching outpatient clinic, the care delivered should be more fine-tuned with the reality of the elderly population in the city and with public policies to respond to this demand.

This situation, associated with the inexistence of studies on the elderly population's health problems in the region the researchers are active in, created the need for this research. Thus, a quantitative study was developed, preceded by qualitative data analysis, aimed at getting to know the reasons that made elderly people living in Tubarão, a city in the State of Santa Catarina, Brazil, seek outpatient care at a basic health service, between 1998 and 2004. It is highlighted that, since 2002, the Family Health Program, nowadays called Family Health Strategy, has been developed at this outpatient clinic.

The results of this research are already being applied, to the extent that they are taken for critical reflection together with managers and health teams at this service, and also introduced in teachinglearning processes with the undergraduate students and faculty members in health who work with the elderly population at the place of study.

As this service is a reference for other services, the authors believe that the results of this research can contribute to the creation of strategies to improve basic elderly health care actions in the region.

The dissemination of these research results aims to encourage researchers, professionals, managers and faculty members in health to perform the same kind of studies in their contexts and particularly to strengthen existing discussions in Brazil about the importance of interdisciplinary health care delivery to the elderly based on their specific needs, with a view to the promotion of healthy aging in the elderly's own context.

\section{METHODS}

This exploratory and retrospective study with a quantitative design was based on qualitative analysis of patient file data of the elderly population attended by the Serviço de Assistência Integrada à Saúde (SAIS), a comprehensive health care service located at Universidade do Sul de Santa Catarina - Unisul, a university in the South of Santa Catarina State.

The researchers found 462 elderly care files between 1998 and 2004, analyzing all files in proper conditions, totaling 401. This inclusion criterion refers to records characterized as reasons to come to the service as manifested by the user. In this paper, this population will be called "elderly users".

In this research, "elderly users" are considered to be people aged 60 years or older. In Brazil, by law, old age starts at 60 , according to official documents: Law 10741/2003, on the Statute of the Elderly, and Decree 2.528, issued on October $19^{\text {th }}$ 2006, which approves the National Elderly Health Policy, which define the age from 60 years onwards to designate the elderly; and Law 8.842/94, which rules on the National Policy for the Elderly, determines in article 20 that "for all effects of this law, any person older than 60 years of age is considered elderly"(6-9).

In the study population, $66 \%$ were women and $51 \%$ were between 60 and 64 years old, $21 \%$ between 65 and 69 years, 16\% between 70 and 74 years and $12 \%$ older than 75 years.

Data were collected through documentary analysis. This technique can be practiced in the context of a documentary research, even when focused on one single type of document, due to the nature of data and the detailed reading and analysis processes. Documents represent a rich and stable data source, as they persist over time and constitute an important data source in any historical research ${ }^{(10-11)}$.

Data analysis comprised four phases. In the first, the qualitative analysis of records, the researchers attempted to identify categories to express the "reasons", resulting in a complex range of "signs and symptoms" and "other situations". The second phase involved the elaboration of data sets related to those categories. In the third phase, these sets were analyzed, looking for correspondence with the International Classification of Diseases (ICD-10), related to the categories " $R$ ", with subcategories from R00 to R99, which includes "symptoms, signs and abnormal clinical and laboratory findings, not 
elsewhere classified", and " $Z$ ", with subcategories from Z00 to Z99, covering "factors influencing health status and contact with health services". In this process, 64 categories were identified, grouped in ICD-10 classifications $\mathrm{R}$ and $\mathrm{Z}$.

The fourth phase was characterized by quantitative data analysis and by the elaboration of representative figures. For this type of analysis, the twenty most frequent categories were selected, which were: R52 (pain, not elsewhere classified); Z76 (persons encountering health services in other circumstances); Z01.3 (examination of blood pressure); R45 (symptoms and signs involving emotional state); Z00 (general examination and investigation of persons without complaint and reported diagnosis); Z01 (other special examinations and investigations of persons without complaint or reported diagnosis); R53 (malaise and fatigue); R06 (abnormalities of breathing); R19 (other symptoms and signs involving the digestive system and abdomen); R42 (dizziness and giddiness); R05 (cough); Z71 (persons encountering health services for counseling and medical advice, not elsewhere classified); R23 (other skin changes); R51 (headache); R60 (oedema, not elsewhere classified); R07 (pain in throat and chest); R63 (symptoms and signs concerning food and fluid intake); R20 (disturbances of skin sensation); R10 (abdominal and pelvic pain) and R11 (nausea and vomiting). The first four categories, which appeared more frequently, were selected for discussion based on literature.

The research project was approved by the Ethics and Research Committee - CEP, at Universidade do Sul de Santa Catarina (Opinion No 05.412.404).

\section{RESULTS}

In the research period, between 1998 and 2004, the 401 elderly SAIS users whose patient files were analyzed presented the health team with 4,634 reasons, involving "complaints" and "requests".

The year-by-year progressive growth in the number of elderly registered at the service is highlighted, with a larger growth in the final year of the study period. This demonstrates that, in parallel with its growth, the elderly population is turning to the Health Service more frequently, seeking care and help to solve its health-disease problems.
Figure 1 presents the progressive growth in reasons to seek the service during the period under analysis.

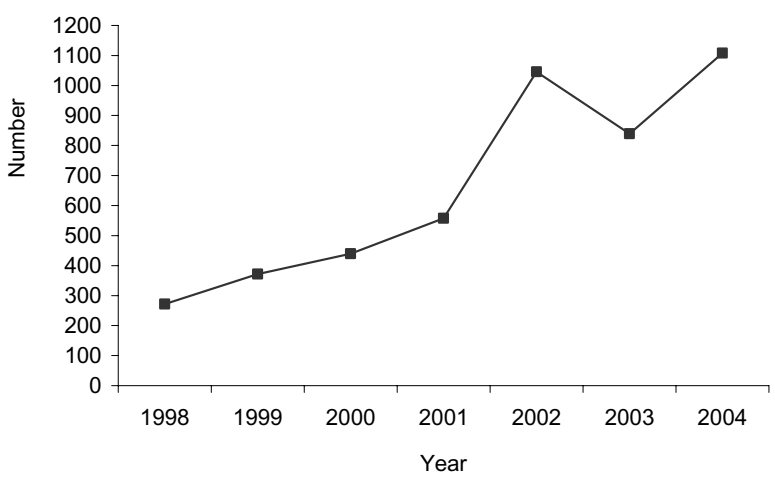

Figure 1 - Elderly IHCS users' reasons to seek care according to the categories $\mathrm{R}$ and $\mathrm{Z}$-Tubarão, SC, Brazil, 1998-2004

Figure 2 presents the distribution of the two main reasons in category $\mathbf{Z}$ and category $\mathrm{R}$, divided per year.

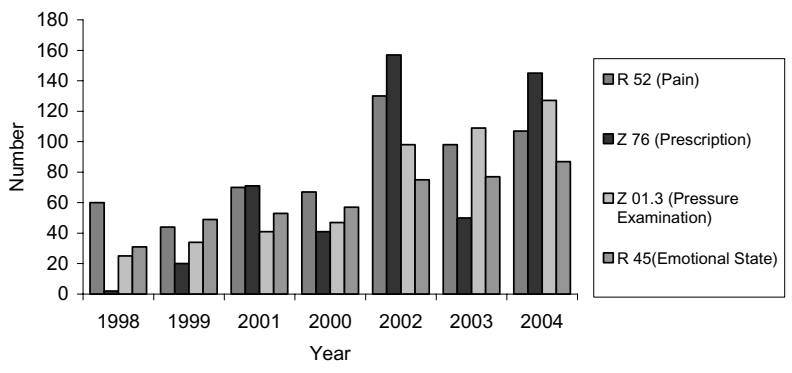

Figure 2 - Elderly IHCS users' reasons to seek care according to the categories R and Z - Tubarão, SC, Brazil, 1998-2004

In 2002, the demand was higher, which may be justified by the end of the implantation process and greater dissemination of the Family Health Program at the SAIS.

According to this research, the list of care delivered between 1998 and 2004, according to ICD10 , showed $64 \%$ in the " $\mathrm{R}$ " category, which represents complaints, translated into signs and symptoms. The most common of these were related to subcategories R52, which indicates "pain, not elsewhere classified", and R45, that is, "symptoms and signs involving emotional state". 
In a study of 990 individuals aged 65 years or older, observations referred to "frequent pain complaints (daily or once or twice per week) in approximately $35 \%$ of participants and occasional pain (once or twice per month) in approximately $29 \%$ of the elderly"(12). That study also highlights that the most commonly reported pains were joint and lumbar, followed by lower limb pains.

The results of the present study support the above data, as the complaints registered on the analyzed patient files indicated "pain in the joints", "in the back", "in the leg", "in the arm", "in the knee", "in the armpit", "in the knuckles", "in the body", "in the bones", "in the shoulder" and "pain in the entire body".

Pain contributes to depression, anxiety, decreased functional capacity and socialization, that is, it decreases the autonomy that, at this age, already tends to be compromised by other factors ${ }^{(13)}$.

The other main category found, equivalent to $36 \%$ of reasons that made the elderly go to the health service, according to ICD-10, referred to the " $Z$ " category, called "requests for attention" here. Although these are not related to "signs and symptoms", they do demand the health team's attention. In this category, the most common subcategories were Z76, related to “persons encountering health services in other circumstances", such as medical prescription and sleeping pill requests, and Z01.3, which refers to requests for "blood pressure examination".

Figure 3 shows the constants of linear equations for the growing trend in the number of consultations per study year, reflecting the line curves: the higher the constant, the greater the inclination, the higher the speed of growth.

It can be observed that Z76 grows faster than R52, and that R45, corresponding to symptoms and signs related to emotional state, although quite frequent, ranks fourth in terms of growth trend.

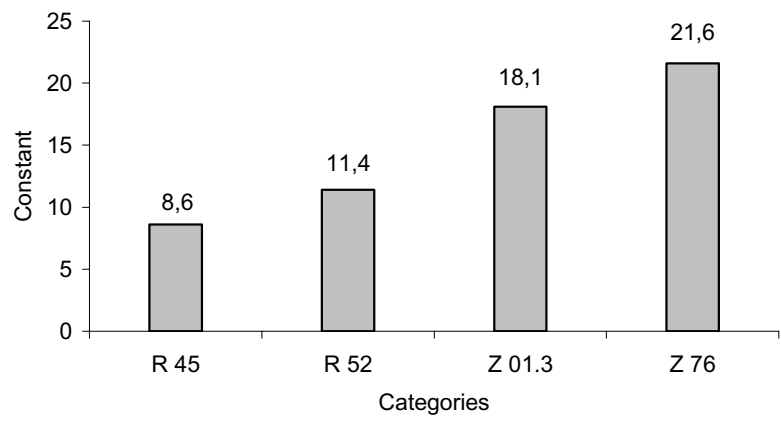

Figure 3 - Growth constant of elderly IHCS patients' reasons to seek care according to the categories $R$ and Z - Tubarão, SC, Brazil, 1998-2004
Based on the comparison between the frequency of Z76 - persons encountering health services in other circumstances -- and its trend over time, it can be inferred that the search for sleeping pills may be associated with psychosocial-existential issues, hence in need of intervention.

It should be emphasized that complaints related to emotional states appear very significantly in the study population, such as "fear" and feeling of "solitude" for example.

The analysis of these complaints appointed situations that may be causing limiting alterations for health, particularly by altering the quality of sleep and rest, the digestive function, to the extent of causing different pains, besides other manifestations. The chronic nature of these symptoms and the limitations of people's autonomy tend to produce manifestations that suggest depression. On the other hand, however, this phenomenon may be accentuating sensitivity to pain.

Nevertheless, it should be highlighted that this picture of depression may be generated by existential suffering. This aspect deserves greater attention from the health team as, according to some authors ${ }^{(14-15)}$, depression in this population is often mixed up with "things typical of elderly people", or with other types of diseases, making it difficult to reach a specific diagnosis for each elderly person.

Depression is an important cause of sleep disorders in aging and tends to be present in this phase of life, especially due to mourning, feelings of abandonment, as well as financial issues and the sensation of identity loss, mostly stimulated by society itself when it devalues elderly people. This situation of suffering, in turn, interferes with the dynamics of elderly people's daily lives, in their autonomy for social activities, giving rise to other signs and symptoms or exacerbating existing complaints.

Qualitative reading also evidenced that some of the complaints presented by the elderly originated in factors connected with people's lifestyle, such as smoking, inadequate eating habits and sedentariness.

\section{CONCLUSIONS}

The variety and frequency of reasons that make elderly people seek the basic health unit evidence, beyond "signs and symptoms" and requests for attention, the existence of complex health 
situations, suggesting the need to develop more specific care to attend to the demands of the elderly population in the studied region.

Pain is a protagonist in the set of complaints and requests for attention presented in this study. It is emphasized however, that elderly people should not be understood as a set of "signs and symptoms", or complaints, about "it hurts here, it hurts there". The particularities of signs and symptoms they present, whether affective, cultural or social, should be analyzed in the context of the elderly citizen and "being".

In this sense, in their practices, basic health care professionals need to develop spaces for listening, including respect, affection and dialogue, broadening knowledge about the health situation that tends to take the form of complaints and requests.

This phenomenon turns basic health care into a more comprehensive care practice as, when they know the subject's life history and current context, there is a greater possibility that the professionals will understand users' health situation better and deliver more humanized and specific care.

Respect for the comprehensive care principle greatly contributes to guarantee health care quality, as this concept comprises the articulated offering of "health promotion, risk factor prevention, care delivery in case of damage and rehabilitation actions, following the dynamics of the health-disease process"$^{\prime(16)}$.

The results also suggest the limitations of the ICD in terms of the need to classify/denominate the health problems people present. In the context of professional practices aimed at comprehensive care, these problems are "situations", most of which are very complex to catalogue and be treated according to predefined care protocols.

The reality of elderly people's expectations and needs observed in this study validates the importance of interdisciplinary work processes in health even more, focused on the particularities of the population, besides the promotion, prevention and treatment actions prescribed to any and all citizens with a view to comprehensive health care.

To achieve comprehensive care, it is essential to add up social actions aimed at mobilizing public and private organizations to promote healthy aging, encouraging the democratization of actions and the reorganization of health systems oriented towards this population.

It should be highlighted that healthy aging needs to be perceived in a broader sense, acknowledging that specific health care, including actions that preserve physical integrity, is important, as well as the elderly people's active participation in social relations, aspiring to their autonomy in the search for independence, making them active members and constructors of society ${ }^{(17)}$.

The aspects raised here become even more important in health service environments that represent teaching-learning spaces for undergraduate health students.

Based on these considerations, ongoing discussions in this area need to be strengthened and contents and practices in comprehensive health care delivery to the elderly population need to be incorporated more emphatically into pedagogical projects of undergraduate health courses.

Another suggestion refers to increased inservice research and training of health managers and teams, directed at comprehensive care delivery to this population and so as to strengthen the practice of the National Health Promotion Policy even further.

Finally, there is a need for educative processes in society, with a view to raising the population's awareness on issues related to aging and how it affects health as a whole, turning this into the most important issue in the social and political sphere, and particularly before the authorities and health professionals working with health promotion. This may guarantee healthy aging to today's youth.

\section{REFERENCES}

1. Silva MC. O processo de envelhecimento no Brasil: desafios e perspectivas. [ homepage na internet]. Rio de Janeiro: Universidade Aberta da Terceira Idade; [Acesso em 20 julho 2005]. Disponível em: http://www.unati.uerj.br/tse/scielo.php. 2. Veras R. Em busca de uma assistência adequada à saúde do idoso: revisão da literatura e aplicação de um instrumento de detecção precoce e de previsibilidade de agravos. Cad. Saúde Pública 2003 junho; 19(3):705-15.
3. Veras R. Envelhecimento populacional e as informações de saúde do PNAD: demandas e desafios contemporâneos. Cad. Saúde Pública 2007 outubro; 23(10):2463-6.

4. Secretaria de Vigilância em Saúde [Página na Internet]. Brasília: Ministério da Saúde; [acesso em março de 2009]. Disponível em: http://www.datasus.gov.br

5. Dias EMP. Processo saúde-doença no envelhecimento. Rev. Científica dos Profissionais de Saúde 2003: (2):121-5. 6. Portaria no 2.528 de 19 de outubro de 2006. Aprova a Política Nacional de Saúde da Pessoa Idosa. [online]. 
Disponível em: URL: http:// www.planalto.gov.br

7. Achutti A, Azambuja MIR. Doenças crônicas nãotransmissíveis no Brasil: repercussões do modelo de atenção à saúde sobre a seguridade social. Ciênc Saúde Coletiva 2004 out/dez; 9(4):833-40

8. Caldas CP. Envelhecimento com dependência. Cad Saúde Pública 2003 mai-jun; 19(3):773-81.

9. Lei o 10741 de 1ㅇ de outubro de 2003. Estatuto do Idoso [online]. Disponível em: URL: http://www.planalto.gov.br/ ecivl_03/leis/2003/L10.741.

10. Gil AC. Como elaborar projetos de pesquisa. 4. ed. São Paulo (SP): Atlas; 2002.

11. Marconi MA, Lakatos EM. Técnicas de pesquisa: planejamento e execução de pesquisas, amostragens e técnicas de pesquisa, elaboração, análise e interpretação de dados. 4. ed. São Paulo (SP): Atlas; 1999.
12. Pimenta CAM, Teixeira MJ. Dor no Idoso. In: Duarte YAO, Diogo MJE. Atendimento domiciliar: um enfoque gerontológico. São Paulo (SP): Atheneu; 2000. p. 372-419. 13. Roach S. Introdução à enfermagem gerontológica. Rio de J aneiro (RJ): Guanabara Koogan; 2003.

14. Neri AL, Von Simson ORM, Cachioni M. As múltiplas faces da velhice no Brasil. Campinas (SP): Papirus; 2003.

15. Caldas CP. A saúde do idoso: a arte de cuidar. Rio de Janeiro (RJ): UERJ; 1998.

16. Campos CEA. O desafio da integralidade segundo as perspectivas da vigilância da saúde e da saúde da família. Ciênc Saúde Coletiva 2003; 8(2):569-84.

17. Inouye K, Pedrazzani ES. Instruction, social economic status and evaluation of some dimensions of octogenarians' quality of life. Rev Latino-am Enfermagem 2007 setembrooutubro; 15 (número especial):742-7. 